\title{
Resourcefulness and Growth of Entrepreneurs in Jos North Local Government Area of Plateau State Nigeria
}

\author{
Dr Edwin S. Echu \\ Department of Business Administration, University of Jos \\ Arinzechukwu Jude Okpara \\ Department of Business Administration, University of Jos, Plateau State, Nigeria
}

\begin{abstract}
Most entrepreneurs moves from one entrepreneurial activities to another, as a result of not be resourceful in their present activity, meanwhile where they are abandoning possesses much better opportunity for their expansion and growth. The point that the study is trying to buttress are those factors responsible to the growth of the entrepreneurs in their activities without leaving their present business or activities for another. Challenges faced by entrepreneurs in their businesses, are more or less similar in nature but varies in their scope. A research questions which includes the roles of fund availability, idea and customer patronage plays in the growth of entrepreneurs in Jos North Local Government Area of Plateau State. The population of the study includes a representative sample of small Businesses (fashion designers, Stylist and Metal Fabricators) within Jos North Local Government Area of Plateau State. The population of the study comprises all the 2401 registered entrepreneurs in Jos North Local Government Area of Plateau State. Yamene's formular for the sample size determination was used to arrive at a sample size of 342, questionnaire method for the study was adapted from (Bradley, 2015; Gora, 2012; Nason and Wiklund, 2018) on resourcefulness which was on a structured and self completion format. The study used SPSS multiple linear regression to present and test the hypothesis. The major findings was that there is a strong significant relationship between idea, fund and customer patronages on the growth of entrepreneurs in Jos North Local Government Area of Plateau State, idea was highly significant at $(\mathrm{t}=4.55)$. Therefore, the study concludes that idea, fund and customers patronage are relevant to the growth of entrepreneurs in their businesses. The study recommends that there should be consistency by entrepreneurs to adopt the culture of innovations through which their resourcefulness would contribute to their growth in their businesses, the implications of the study implies when adopted practically and theoretically it will yield a positive impact on the policy makers to enhances the resourceful nature of entrepreneurs in Nigeria
\end{abstract}

Keywords: Resourcefulness, idea, Fund, customers patronage, Growth, Entrepreneurs and Innovation.

DOI: $10.7176 / \mathrm{EJBM} / 12-4-01$

Publication date: February $29^{\text {th }} 2020$

\subsection{INTRODUCTION}

Growing a business is no easy challenge to most businesses and yet it is a great desire and an expectation for most entrepreneurs to grow after some few years of operation. With their hunger and need for growth of businesses on the rise, it has become imperative that entrepreneurs seek growth opportunities and strategies daily.

There is a trend that entrepreneurs do not last in one activity they engage themselves, due to lack of resourcefulness on individuals capacity, attitudes and economic condition that is unfavorable to attempt, resourcefulness is the best resource on the planet.

In fact, living in the information age with the use of technology, being resourceful is literally at your fingertips. The ability to be resourceful is a personality trait that allows a person to create solutions with limited resources. While many people think of the need to be resourceful based on everyday terms of money, time and energy, resourcefulness is obtained through proper mental, physical and emotional health, the study was based on the point, to introduce to entrepreneurs, the patterns of being resourceful which in turn pave way for their growth in their business (Schillo,2011).

Entrepreneurship is a process of opportunity identification and the creation of an organization to exploit the opportunity. Entrepreneurial orientation is the individual's inclination to take on pioneering, proactive and risk taking behavior to start new venture. It refers to the processes, practices, and decision-making activities that lead to the new entry (Lumpkin and Dess, 1996).

Entrepreneurial resourcefulness refers to the ability to self-regulate and direct one's behaviour to successfully cope with difficult, stressfulness and challenging situations (Meichenbaum, 1977). Entrepreneurial resourcefulness comprises of three generic competencies - cognitive, affective and action-oriented (Kanungo \& Misra, 1992). The competencies refer to the mental capabilities that help successful adaptation to the difficulties posed by the external environment, it is the constellation of functions, activities and actions involved in the perception of opportunities and the creation of organizations. Entrepreneurial behaviour is a function of 
entrepreneurial resourcefulness. Sasi and Sendil (2000) argue that by positing that entrepreneurial resourcefulness influences entrepreneurial behaviour, the predictive power can be enhanced.

Innovativeness has become an important factor used to identify rapid growth of entrepreneurship activities; many believed that resourcefulness is the specific tool used by entrepreneurs to grow in their businesses, resourcefulness which involves the exploitation of new ideas, with their claims that resourcefulness is the ability to take quick advantage of scientific or technological discoveries, commercializing them in ways that translate the new discoveries into added-value goods and services and processes for their customers/clientele (Tidd and Bessant ,2011).

However, there are no much study done on the aspect of resourcefulness in relation to growth of entrepreneurs, looking at the separate concept which has been emphasized upon, the study hinges on the growth of entrepreneurs and the ability to think out of the box; with the concept of being resourceful in pursuit of their growth (Bradley, 2015). The entrepreneurship process consists of constant search for alternatives, certain amount of risk taking, perseverance and attempts to identify and utilize opportunities for economic betterment (Rogers, 2003).

In other words, the greater the problems, the greater the non-performance of enterprises leading to lesser growth in terms of investment and employment (Gangadhara,2006). Every entrepreneur desire to attain to growth within the shortest possible time, but in the process, they were seriously handicapped by the rigid institutional set up (funding), market imperfection (low customer patronages), traditional value system (idea, culture) etc (Chanambam, 2006).

Entrepreneurs in Jos North Local Government Areas of Plateau State, faces an entire different drawback that hindered their growth, which are unavailability of fund, lack of ideas and low customer patronages(Ogwo and Igwe 2012). As a result of their socioeconomic, geographical and cultural diversities.

The increase of entrepreneurs in the Jos North Local Government Areas of Plateau State, is lagging far behind compare with other regions of Nigeria. In spite of the huge potential for different types of resources, yet there are no application of resourcefulness concept in their businesses.

Against these backdrops, the researcher came up with the study resourcefulness and growth of entrepreneurs in Jos North Local Government area of Plateau State.

There are clear evidence that entrepreneurs are not resourceful which limit their growth in their business, it showed lack of resourcefulness by entrepreneurs, making them to move from one activity to another, whereas there are many opportunities in the area they are abandoning; thereby attributing it to lack of ideas , unavailability of fund, and low customer patronage (Bradley, 2015).

Lack of Ideas possess as fundamental factors upon which growth of an entrepreneurs can be achieve, when an entrepreneur is working towards growth and lacks proper ideas of positioning, such deficiency causes fundamental drawback towards growth of entrepreneurs it stands as an obstacle towards growth of entrepreneurs in their activity. The problem encountered as a result of lack of ideas is not limited to any place or any activity, many of the entrepreneurs do not spend in aspect employing think-tank personnel that can upgrade their businesses, rather their chooses to run the business on their own, thereby no yielding to the state of not been resourceful in their activities, which possibly lead to wind-up (Dhameja, 2017).

Unavailability of fund which is the main factor of resourcefulness, finance stands as the life-blood of modern business growth and it is the most important factor upon which growth of entrepreneurs and their enterprises can be achieved, without the availability of adequate financial resources the smooth running of the business will not be successful. Usually entrepreneurs started well in the initial stage but somewhere down the line in their operation they miss the route to success as a result of unavailability of fund (Moses and Adebisi , 2013).

Which is also in line with (UNWO,2006), it is also among the factors that account for low customer's patronage especially in Jos North Local Government Area of Plateau State, since the act of patronages plays important roles in the growth of entrepreneurs, because with low customers patronages product and services invented by entrepreneur would end up with them, meaning that there are low sales and profit from customers patronages, which makes the entrepreneurs not to be resourceful and end up limiting their growth rate (Gora, 2012).

On the other hand, low customers patronage is the major problem facing the handcraft producer and other entrepreneurship activities in Nigeria according (Dickson, 2018).

Besides, Jos North Local Government Area of Plateau State is one of the major commercial centers in Plateau state, these Issues raised forms the crux of the study, which contributes to the lack of resourcefulness against this backdrop the researcher came up with this study to bridge the gap, which is on the topic resourcefulness and growth of entrepreneurs in Jos North Local Government Area of Plateau State Nigeria.

The study has three research questions which was used in bringing out the objective and hypotheses of the study, the research questions:

a. What are the effect of ideas to the growth of entrepreneurs in Jos North Local Government Area of 
Plateau State?

b. What is the impact of availability of fund to the growth of entrepreneurs in Jos North local Government Area of Plateau State?

c. What impact does customer's patronage has to do with growth of entrepreneurs in Jos North Local Government Area of Plateau State?

\subsection{LITERATURE REVIEW CONCEPTUAL REVIEW}

Experience suggests that when developing research questions, it is beneficial to diagrammatize neither the problem nor the topic, this is often called conceptual framework. According to (Adefile, 2008). A conceptual framework explains either graphically or in narrative form, the main things to be studied such as the key factors, construct or variable and the presumed relationship among the variable.

A diagram of research topic is literally worth more than millions of words (Adefila, 2008). The task here is to create a diagram of a topic of study which includes clearly defined variables (independent and dependent) along the relationship of those variables and key factors that influence the variables.

Based on the concepts, which drives the points that states for entrepreneurs grow their various activities, there is an objectives which will have a relationship on idea, fund and customer patronage, these three independent variables which are among the tools that aid entrepreneurs to be resourceful and pave way for growth in their activities, which will definitely lead to growth of the business and not winding up of the business (Rose, 2006).

It portray the fact that where entrepreneurs strive for growth in their various activities, they do that by being resourceful, which will enables them to grow their business within any given society.

\section{Entrepreneurial finance}

In recent years, entrepreneurial finance literature has experienced a substantial makeover. Not only have new phenomena such as crowd-funding emerged, but also researchers have highlighted the existence of finance sources for ventures that were originally thought to be precluded to them (e.g. bank debt).

These new trends call for a significant reorganization of our understanding of how entrepreneurs finance and grow their ventures. In the following sections, we will (a) explore "new" sources of finance for start-ups such as crowdfunding, (b) challenge common wisdom with respect to how "traditional" sources of finance support ventures' development, (c) illustrate how the internationalization of capital markets is impacting ventures' prospects, and (d) provide directions for future research and theory building.

\section{New sources of financing}

Until recently, the usual financing cycle started with the three "Fs" representing friends, family, and "fools", followed by business angels, VCs, and capital markets (e.g. IPO). Entrepreneurs looking to raise seed finance usually turned to their close ties. They developed a prototype, approached the first clients, and hopefully generated revenues. Once these initial milestones were achieved, entrepreneurs started enlarging their circle of financiers with business angels.

These wealthy and well-connected individuals usually provided capital to expand. At this stage, the venture was supposed to grow substantially in order to be appealing to institutional investors such as VCs. For many entrepreneurs, obtaining VC funding was already a significant achievement, a stamp of quality and success. VCs were considered a valuable sign of legitimacy (Stuart, Hoang, and Hybels 1999 Stuart, T. E., H. Hoang, and R. C. Hybels. 1999). Inter-organizational Endorsements and the Performance of Entrepreneurial Ventures." and an important source of advice and contacts (Bellavitis, Filatotchev, and Kamuriwo 2014).

However, this funding cycle has to be re-conceptualized. Entrepreneurs in science and technology start-ups can raise financing from numerous sources that were not available until recently. New sources include accelerators and incubators, proof-of-concept centers, university-based seed funds, and crowd-funding platforms. These sources offer peculiar advantages and disadvantages and can be accessed during different moments of the firm's life cycle, many times interchangeably. These new dynamics pose strategic challenges to entrepreneurs and offer interesting theoretical opportunities.

\section{Entrepreneurship and Resourcefulness}

Conceptual and theoretical relationship between entrepreneurship and resourcefulness for years has been investigated in the literature. Economic principles of innovation attract increasing attention focused in recent years. Entrepreneur pattern goes back to the 1930s, for the first time, (Schumpeter,1934) tried to find a relationships between entrepreneurs and resourcefulness through innovators and entrepreneurs as being resourceful. He plays a large role in the economic development of entrepreneurs and assist them in growth, because entrepreneurs are generating innovations.

Resourcefulness has been defined as a community's capacity to engage with their local resource base as a means to address the unequal distribution of resources (Franklin,2018). Moreover, resourcefulness privileges civic engagement and traditional knowledge exchange, and, similar to social innovation, attempts to empower 
local communities (MacKinnon and Derickson, 2012 ). Identifying assorted conditions and processes in which resourcefulness operates would greatly benefit planning and policy research. Furthermore, despite their overlapping qualities and socially relevant potential, the academic connection between social innovation and resourcefulness has not yet been made.

The concept of the growth of entrepreneur as a resourceful tools, entrepreneur, forms the foundation model in which the entrepreneur resourcefulness could be view through innovation.

Entrepreneurs do not innovate merely to seek for opportunities, often its about identifying a "forgotten" area of business, opportunities or niche area of business where customers' needs are not yet adequately met (OECD, 2011). These opportunities are those that large firms either ignore, seek not to produce, or cannot physically create or manufacture. Entrepreneurship in itself does not guarantee innovation.

\section{RESOURCEFULNESS OF ENTREPRENEURSHIP}

Either alone or together with incumbent firms, innovative entrepreneurs achieve innovation outcomes such as inventions, patents, novel products, or new business models. These innovation outcomes can have substantial and various consequences at the individual, firm, industry, region, or even the country level. As noted in the introduction, innovative entrepreneurship can be a source of individual and regional wealth generation as well as societal progress. Multiple studies investigate the effect of innovation on firm survival (e.g., Boyer and Blazy, 2014; Tsvetkova, 2014; Howell, 2015; Hyylinen, 2015), which has also been briefly discussed in the subsection on innovation and firm exit. On the one hand, it is argued that innovativeness fosters survival-enhancing attributes (e.g., market power and cost efficiency) and capabilities (e.g., absorptive capacity). On the other hand, an innovative start-up faces (and bears the associated risks of) liabilities of newness and smallness that exceed those of its non-innovative counterparts.

The prevailing view in the empirical literature appears to be that there is a positive association between firms' innovativeness and their subsequent survival (Helmers and Rogers, 2010; Wagner and Cockburn, 2010). Nevertheless, there is emerging empirical evidence suggesting that these results may be context dependent, and may not necessarily be applicable to younger firms (Boyer and Blazy, 2014; Hyytinen et al., 2015). Thus, this issue remains an open question.

\section{THEORETICAL FRAMEWORK}

This work anchored on the underpinning, and supporting theories that add value to the literature of the study. Contingency Theory

Contingency theory's core concept of fit suggests that a proper alignment among internal and external organizational factors will positively affect business performance. To understand the basic assumptions about contingency theory, the study will briefly cover the history and the origins of contingency theory, since it is adopted in the work as a complimentary theory.

Contingency theory stems from a criticism of the so called universal approach that had dominated the management science. That is, a number of scholars challenged the idea of the one best way (Woodward, 2005). shows that to organize and structure a firm efficiently there are contingencies that need to be accounted for, or in other words, that business structure's effect on firms performance 'depends' on contextual aspects that need to be taken into consideration.

\section{Resource- Based Entrepreneurship Theory}

The Resource-based theory of entrepreneurship argues that access to resources by founders is an important predictor of opportunity based entrepreneurship and new venture growth. This theory stresses the importance of financial, social and human resources (Aldrich, 2009). Thus, access to resources enhances the individual's ability to detect and act upon discovered opportunities (David and Honing, 2003). As adopted in the study as supporting theories of the variables that support the skills, funding and the patronage aspect of the customers, which financial, social and human capital represents three classes of theories under the resource-based entrepreneurship theories

\section{Conceptual Framework}

The research framework depicts that the dimensions of innovation: idea, Fund and high customer patronage each has a direct linear relationship with entrepreneurs growth. 


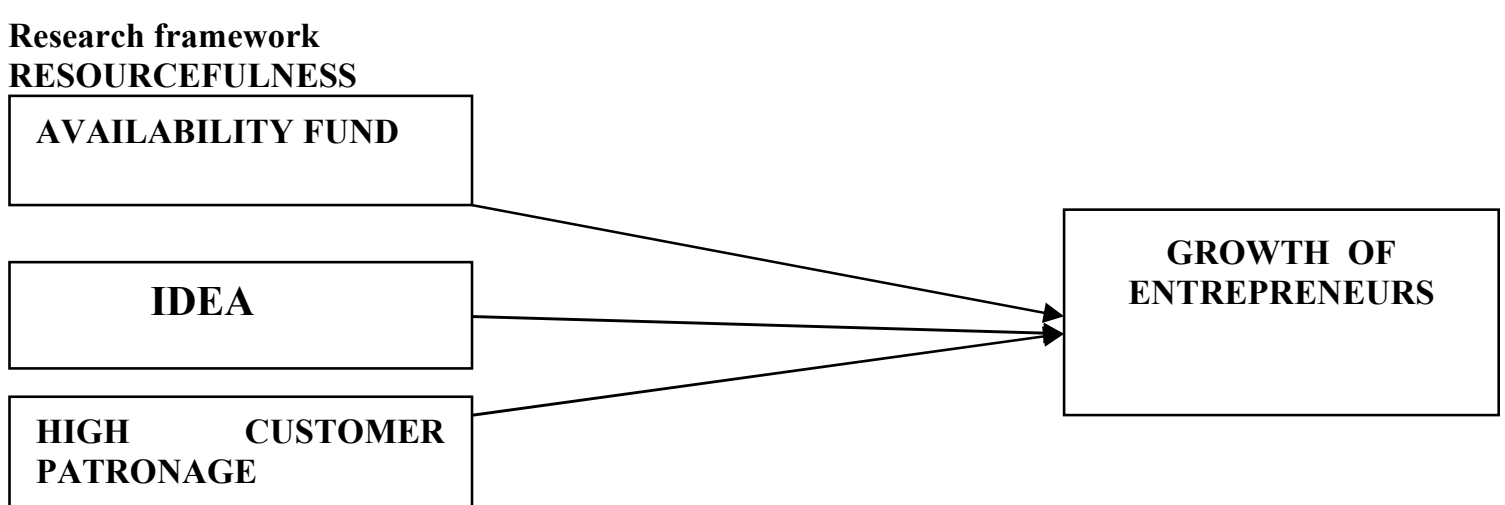

Figure 1

(Adapted from Bradley, 2015 and Gora, 2018).

a) Ideas and entrepreneurs growth

Idea demonstrates that self-efficacy is important for understanding why an attractive idea may lead an entrepreneur to develop passion and grow in their activities, it was discovered that idea plays a good role in entrepreneurs activities.

However, entrepreneurs increases self-efficacy and add their individual concepts to develop their skills, that is based on classic entrepreneur. This instills individual self-efficacy beliefs, which in turn are prerequisites for the entrepreneur passion to grow towards their activities. Looking at the strong relationship between ideas and entrepreneurs growth especially in their entrepreneurial activities.

Resourcefulness in the entrepreneurship context as skills and ideas for dealing with problems, especially those of novelty, in the pursuit of an opportunity, the construct are still under-going development (Bradley, 2015).

b) Fund and entrepreneurs growth

Entrepreneurs have differing growth objectives and may be at different stages in their own lifecycle and the lifecycle of their ventures. Many entrepreneurs, for example, are motivated by lifestyle factors and may have little need for external finances. Others, whilst having future growth plans, may not yet be ready to grow (Bhaumik, Fraser and Wright 2015).

There are also other complexities, entrepreneurial cognition influences the decision to seek external finance by affecting perceptions of growth opportunities and/or the desire/perceived ability to exploit these opportunities. Start-up entrepreneurs may be reluctant to let go of control but also established family firms with underlying growth prospects may be reluctant to take on external funding that either dilutes family ownership or involves taking on debt that would put family ownership at risk in the event of difficulties in servicing the debt. Previous research has looked at different parts of the relationship between entrepreneurial finance and growth: capital structure and sources of finance; market failure in the supply of entrepreneurial finance; internal/personal finance constraints on growth; and the special role of venture capital in building high growth firms (Steinberg, 2012).

Resourcefulness in the entrepreneurship context as financial for dealing with problems, especially those of novelty, in the pursuit of an opportunity, the construct are still under going development (Bradley, 2015).

The relationship between fund and entrepreneur growth shows that there positive link between fund, which plays a role as a catalyst that boost entrepreneurs in their entrepreneurial activities (Fraser, 2015).

c) High customer patronage and entrepreneurs growth

From the foregoing therefore, it is observed that the foundation for retaining customer patronage is laid not at the point of service delivery but rather at the stage of enterprise formation. Furthermore, innovativeness, as a functional attribute of entrepreneurship must be adopted across board in running the business. Entrepreneurs need to be versatile and flexible in their decisions with regards to packaging, content analysis and promotion. One opportunity that could be tapped now is the growing concern. What remains is the proper packaging and promotion; all at the appropriate price (Cherkassky, 2006).

Customer patronage plays a high role in resourceful nature of entrepreneurs in seeking and searching for an opportunities, through patronages entrepreneurs generate revenues which prompt growth of the business (Gora, 2012). Customers patronages as a dimension of resourcefulness is among the many dimensions under-going development (Bradley, 2015).

d) Entrepreneur Growth

Innovation can be radical and incremental. Radical innovations refer to path-breaking, discontinuous, revolutionary, original, pioneering, basic, or major innovations (Green, 1995). Incremental innovations are small improvements made to enhance and extend the established processes, products, and services. However, this contradistinction does not "necessarily [correspond] to the more fine-tuned reality" because "radicality is a continuum" (Katila, 2002) Such a broad understanding of innovation is particularly meaningful within the 
context of innovative entrepreneurs insofar as upgrading technology or improving skills may lead to more efficient uses of resources or higher-quality outputs, but not necessarily to new products or patents. That is why (Lundvall, 2007) emphasized that it is important to avoid a high-tech bias when thinking about innovation.

Pragmatic views of growth has it as the successful implementation of creative ideas (Woodman, 1993) or 'as a process that provides added value and a degree of novelty to the organisation and its suppliers and customers through the development of new procedures, solutions, products and services as well as new methods of commercialization which leads to expansion' (McFadzean ,2005).

Some experts consider improvement as being the specific tool by which entrepreneurs exploit opportunities. The research to date focuses mainly on innovativeness as a personal trait (Rauch, and Frese, 2007; Mueller, and Thomas 2000) or, alternatively, innovativeness at the firm-level (Covin, Slevin, 1989; Rauch, Wiklund, Lumpkin, Frese, 2009).

Resourcefulness can be described as willingness and interest to seek original ways of action. This conceptualization does not imply the introduction of innovative products, but rather, more a preference to engage in creativity and experimentation (Rauch, 2010). It assists entrepreneurs to recognize valuable opportunities and to search for new ways of task completion, which makes them to grow in their activities through maximizing profit (Ward, 2004).

\subsection{METHODOLOGY}

According to Bryman and Bell (2011), a research design provides a framework for the collection and analysis of data in a research process. A choice of research design reflects decisions about the priority given to a range of dimensions of the research process. In this study, a cross-sectional (survey) design was used.

The design was found appropriate because it entails the collection of data on more than one case and at a single point in time in connection with many variables which were then examined to detect patterns of association (Bryman and Bell, 2011). Typically surveys attempted to describe what was happening or to learn the reasons for a particular activity.

However, going by reality of this study, which might be different from each of us, going by our unique understanding of the world and our own experiences, based on this study reality in this context is completely a subjective phenomenon, and cannot be shared by anyone (Ashworth,2003).

This study adopts the positivist orientation, which states that the researcher has a perception of the world around him, since the (researcher) is the constructor of such world around him. Positivist provides different perceptive points with which to view the world that allows the unique difference of individuals to come into focus while at the same time permitting the essential sameness that unites human beings to be identify (Ashworth,2003). Meaning that it is necessary that sharing views of others helps to enhance knowledge, that none will alter such (Gergen,2009). Pointing out that each individual point of viewing reality is true for them, since they experienced such.

\section{POPULATION OF THE STUDY}

The population includes a representative sample of entrepreneurial Businesses within Jos North Local Government. The population includes all entrepreneurs who are into entrepreneurial activities in Jos North. According to PLASMEDA 2018, the total populations of entrepreneurs that registered their businesses in Jos North Plateau State are 2401.

Therefore confirming the report from (Ministry of industry, 2017). That about 2349 entrepreneurs registered their businesses in Jos North Local Government Area of Plateau State. Therefore this research adopted the Yamane formula to determine the sample from the population of entrepreneurs in Jos North. The sampling unit for this study was individual entrepreneurs (owners) of Businesses within Jos North Local Government Area of Plateau State.

\section{SAMPLE SIZE DETERMINATION}

Sample size can be seen in the Table 3.1:

\begin{tabular}{lll}
$\mathbf{S} / \mathbf{N}$ & Type of Entrepreneurial Activities & No of Questionnaire \\
1 & Fashion designers & 140 \\
\hline 2 & Stylist & 102 \\
3 & Metal Fabricators & 100 \\
& Total & $\mathbf{3 4 2}$ \\
\hline
\end{tabular}

Source: from PLASMEDA 2018

The decision about sample size is not a straightforward one as it depends on a number of considerations and there is no one definitive figure (Bryman and Bell, 2007). Among important considerations include time and cost, non-response rate, heterogeneity of the population, kind of analysis intended, the magnitude of accept error and the confidence level (Zikmund, 2010). 
Based on the above table 3.1 above; the sample for the study was determined using, (Yamane , 1973). formular which states this

$$
\begin{aligned}
& \mathrm{N}=\frac{\mathrm{N}}{1+\mathrm{N} \mathrm{e}^{2}} \\
& \text { Where } \mathrm{n}=\text { the sample size } \\
& \mathrm{N}=\text { The total population } \\
& \mathrm{E}=\text { Error margin (which is normally } \% \text { or } 0.005) \\
& \mathrm{I}=\text { mathematical constant } \\
& \text { The margins of error were } \% \text { or } 0.10 \% \text { which was chosen voluntarily by the said research. } \\
& \text { Therefore substituting the formula above. } \\
& \mathrm{n}=\quad \frac{2401}{1+2401 \times 0.005^{2}} \\
& \quad \frac{2401}{\mathbf{n}=} \\
& \mathbf{n}=\quad \mathbf{n}=\mathbf{3 4 2} \text { population of the study }
\end{aligned}
$$

\section{METHOD OF DATA COLLECTION}

Questionnaire is a means of data collection that has been approved to be the most appropriate tool in exploratory research studies (Saunders, Lewis and Thornhill 2007). The questionnaire was adapted from (Nason and Wiklund, 2018, \& Gora, 2018) questionnaire on resourcefulness and it was a Structured and Self-completion questionnaires including closed-ended questions were given to the entrepreneurs selected for the study (Fashion designer, Metal Fabricators and Stylist), questionnaire will also be tested to handful of 20 entrepreneurs within Angwan Rukuba area. In the questionnaire there were the likert scale questions where respondents were asked the extent to which they agreed or not agreed with underlying statements on each item. For each statement (for example, $\mathrm{i}$ am able to deal effectively with unexpected events). The scale included the choices 1(disagree), 2 (Strongly disagree), 3 (neutral), 4 (agree) 5 (strongly agree).

\section{Validity of research instruments}

\section{Table 3.2:}

\begin{tabular}{ll}
\hline Variables & \\
Entrepreneurs' growth' & 0.83 \\
\hline Availability of fund & 0.71 \\
Ideas & 0.72 \\
Customer Patronage & 0.77 \\
\hline
\end{tabular}

Table 3.3:

\begin{tabular}{lll}
\hline Cronbach's Alpha $^{\mathrm{a}}$ & Cronbach's Alpha Based on Standardized Items $^{\mathrm{a}}$ & $\mathrm{N}$ of Items \\
\hline-.396 & -.451 & 4 \\
\hline
\end{tabular}

\section{Reliability of the Research Instrument}

Reliability test ensures that the instrument measures consistently as required. It also shows the extent to which the researcher can confidently rely on the information obtained through the use of the instrument adopted to gather data for the research work.

Consequently, data collected were subjected to reliability analysis to establish the reliability of the measures and ensure consistent measurement among the various measurements in the instrument. Analysis to the reliability of coefficient would be used. The reliability measures were justified using the works of (Goode and Hatt, 2000).

\section{METHODS OF DATA ANALYSIS}

Data analysis is an application of reasoning to understand, clear and interpret the data that have been collected through the questionnaires (Zikmund et al., 2010).

\section{Multiple Linear Regression Analysis}

According to Sekaran and Bougie (2010), multiple linear regression analysis is an analysis of association which the effects of two or more independent variables on a single, interval-scaled dependent variable. 


\subsection{FINDINGS}

\section{Profile of the Respondents}

\section{Demographic Distribution of Respondents}

The respondents were distributed according to following demographic criteria as shown on Response rate and of demographic distribution of respondents can be seen in table 4.1 above'

A total of 350 questionnaires were distributed to the target population. This consisted of Fashion designers, Stylist and Metal Fabricator workers. The number of questionnaires distributed included Fashion Designers with a total of 140, stylist with a total of 102 while metal fabricator worker with a total of 108 . Out of the 350 questionnaires distributed, a total of 342 were returned which represents a response rate of $92.9 \%$.

This response rate was satisfactory to draw conclusions from the study and was, therefore, representative. A response rate of 50\% is adequate for analysis and reporting, a rate of $60 \%$ is generally good while a response rate of above $70 \%$ is excellent (Mugenda and Mugenda, 2009). This is also the same position taken by (Babbie, 2010). Who also asserts that a response rate of above $70 \%$ is deemed to be very good.

Table 4.3: Multicollinerity test based on tolerance Value and VIF

\begin{tabular}{lll}
\hline Independent Variable & Tolerance & VIF \\
Idea & .012 & 1.000 \\
Fund & .011 & 1.000 \\
C-Patronage & .010 & 1.000
\end{tabular}

Source: Researcher

Multicollinearity is a quandary that occurs when independent variables are not interrelated to as high as 0.8 and above (Tabachnick and Fidell,2007). When two or more construct are interrelated, they enclose unnecessary data and for such reason. Not all of the data are required in the same analysis. Since they increase the size of error and thereby weaken the analysis.

However if it is found it will only be deleting the offending variables. To screen for multicollinearity , Variance Inflation Factors (VIF) and tolerance level were examined through Regression result from SPSS, based on the general rule which state that the cut of point should not exceed 10 and not less than 0.10 (Hair et al.,2010), Table 4.3; it is clearly shows that tolerance ranges between $0.12-0.12$ significantly and less than 10 . In the same way, VIF ranges from 1.000-1.000 and it is good enough as being $<10$ (Tabachnick and Fidell,2007). Meaning that there was no multicollinearity issue among the variables used in the study. Multicollinerity test based on tolerance Value and VIF are contained in Table 4.3 above.

\section{TEST OF HYPOTHESES}

Table 4.4: Result of Hypothesis

\begin{tabular}{lllllll}
\hline Hypothesis & Relationship & Std Beta $(\beta)$ & Std. Error & T-Value & P-Value & Decision \\
\hline H1 & Fund $\rightarrow$ EG & .603 & .011 & 5.4516 & 0.000 & Reject \\
H2 & Idea $\rightarrow$ EG & .610 & .012 & 5.5160 & 0.000 & Reject \\
H3 & CG $\rightarrow$ EG & .5403 & .010 & 6.510 & 0.000 & Reject \\
\hline
\end{tabular}

Source: Researcher

It shows the standard path coefficient $(\beta)$. Standard error. T-values, $p$-value and decision taken. And all the relationships are represented by standardized beta value. In testing the relationships, the significance level was at $\mathrm{p}<.05$ and $\mathrm{p}<.01$ (Hair et al.,2010).

As indicated in table 4.4 above the three direct relationships between the independent variables and dependent variable showed a strong positive significant effects, which includes (1) Availability of Fund (F) and entrepreneurs' growth $(\mathrm{EG})(\beta=0 .-603: \mathrm{t}=5.5160 \mathrm{p}<0.000)(2)$ Idea $(\mathrm{I})$ and entrepreneurs' growth $(\mathrm{EG})(\beta=0.610$ : $\mathrm{t}=5.4516 \mathrm{p}<0.000)$ Customer patronage $(\mathrm{CP})$ entrepreneurs' growth $(\mathrm{EG})(\beta=0.5 .403: \mathrm{t}=6.510 \mathrm{p}<0.000)$.

\section{DECISIONS}

Hypothesis I: Availability of fund does not have significant on growth of entrepreneur in Jos North Local Government Areas of Plateau state. This hypothesis is accepted based on SPSS output, which showed that there is a statistically significant relationship between availability of fund and growth of entrepreneurs.

Based on the relationship between the construct which is positive $(\beta=0 .-603: t=5.5160 p<0.000)$. The relationship between the three variables is strongly significant at $p<0.000$ with a relatively high beta value and tvalue $<5.51$

Therefore it indicates that availability of fund has a strong influence on the growth of entrepreneurs in Jos North Local Government Area of Plateau State. Therefore the null hypothesis is rejected.

Hypothesis II: Ideas does not have any significant impact on growth of entrepreneurs in Jos North Local Government Areas of Plateau state. This hypothesis is accepted based on SPSS output, which showed that there is a significant impact between ideas and growth of entrepreneurs.

Based on the relationship between the construct which is positive $(\beta=0.610: t=5.4516 p<0.000)$. The 
relationship between the variables is significant at $\mathrm{p}<0.000$ with a relatively high beta value and $\mathrm{t}$-value $<5.41$. Therefore the relationship is supported while the null hypothesis is rejected.

Therefore it is indicated that idea has a strong impact on the growth of entrepreneurs in Jos North Local Government Area of Plateau State.

Hypothesis III: Customer patronage does not have any significant impact on growth of entrepreneurs in Jos North Local Government Areas of Plateau state. This hypothesis is accepted based on SPSS output, which showed that there is a significant impact between customer patronage and growth of entrepreneurs.

Based on the relationship between the construct which is positive $(\beta=0.5 .403: t=6.510 \mathrm{p}<0.000)$. The relationship between the variables is significant at $\mathrm{p}<0.000$ with a relatively high beta value and $t-v a l u e<7.10$. Therefore the relationship is supported while the null hypothesis is rejected.

Therefore it indicates that customers Patronage has a strong impact on the growth of entrepreneurs in Jos North Local Government Area of Plateau State.

\subsection{CONCLUSION AND RECOMMENDATION}

From the above summary the study concluded that, entrepreneurs in this 21 st century are faced with enormous challenges especially where the world economy has been globalized, they are faced with more complexities, competition and structural changes which elicit the introduction of resourcefulness within their businesses.

Ideas which is the bedrock of resourcefulness and plays important role in such activities and explains the direction of any entrepreneurs, the study found out that negative ideas would always bring the business or entrepreneurial activities stagnant. When positive ideas are involved in the business it automatically lead to growth of such enterprises or businesses.

Availability of fund remains the vital factor upon which entrepreneurs can grow in their businesses, meaning that access to funding would bring out the hidden potentials in any entrepreneurs and urge them to seek for growth in their entrepreneurial activities.

When there is high customers patronages it would currently boost the positions of entrepreneurs making it completely importance in the market with a good product, high customer patronage makes the entrepreneurs to be relevant to the entrepreneurial activities especially in sales and revenue generation and growth of businesses.

\section{REFERENCES}

Adefile , A. (2008). The $10 \mathrm{Ms}$ of business success. A straight-to-the point guide to running your $S M E$ efficiently and effectively. Lagos. Bookbrands International.

Aldrich, H. E., E. R. Auster. 1986. Even dwarfs started small: Liabilities of age and size and their strategic implications,. Res. Organ. Behavior8(1) 165-198.

Alvidrez, J., Azocar, F., \& Miranda, J. (1996). Demystifying the concept of ethnicity for psychotherapy researchers. Journal of Consulting and Clinical Psychology, 64, 903-908.

Armstrong, M. (2006). Human resource management practice. London and Philadelphia: Kogan Page Limited.

Ashworth, P. (2003). An Approach to Phenomenological Psychology: The contingences of the life world Journals of Psychology 34 (2):145-156

Bailey, K.D. (1987). Methods of Social Research. 3rd Edition, New York: The Free Press.

Baker, T., \& Nelson, R. E. 2005. Creating something from nothing: Resource contribution through entrepreneurial bricolage. Administrative Science Quarterly, 50: 329-366.

Baldwin, S. A., Murray, D. M., \& Shadish, W. R. (2005). Empirically supported treatments or type I errors? Problems with the analysis of data from group-administered treatments. Journal of Consulting and Clinical Psychology, 73, 924-935.

Bast, F. (2001),"A review of three decades of doctoral studies using the principal instructional management rating scale: a lens on methodological progress in educational leadership", Educational Administration Quarterly, Vol. 47 No. 2, pp. 271-306.

Barringer, I.,Hanz, W \& James, R. T. (2001). Start-up capital: does gender matter? Small Business Economics. $16,329-345$.

Benjamin, A. S., Bjork, R. A., \& Schwartz, B. L. (2011). The mismeasure of memory: When retrieval fluency is misleading as a met mnemonic index. Journal of Experimental Psychology: General, 127, 55-68.

Becchetti, L. and G. Trovato (2002). The Determinants of Growth for Small and Medium Sized Firms. The Role of the Availability of External Finance, Small Business Economics 19(4): 291-306.

Bellavitis, J., Filatotcher, M.S., \& Kamuri, J.B. (2014). Consumers decision making in street food purchasing and food safety in Nakhon si Thammarat province Thailand. International Journal of social science and humanity, vol. 5 (3), pp. 306-310.

Bhumik, N., Fraser, M..M. \& wright, J. (2015). Managing an organisational learning system by aligning stocks and flows, Journal of Management Studies, 39 (4), 437-69.

Boeddrich, U. (2004). Research methods for business(4th ed.). Hoboken, NJ: John Wiley \& Sons. 
Boyer, M. B., \& Blazy, A. M. (2014). Qualitative data analysis: A sourcebook of new methods. Beverly Hills, CA: Sage.

Boyer, M. B., \& Blazy, A. M. (2014). Qualitative data analysis: A sourcebook of new methods. Beverly Hills, CA: Sage.

Bradley, S. W. (2015). Entrepreneurial resourcefulness. Wiley Encyclopedia of Management, 3: 1-3

Bryman, A., and Bell, E., (2011). Business research methods ( $3^{\text {rd }}$ ed). Oxford University Press.

Bums,T.,andStalker,G.M.,1961,The Management of Innovation, Tavistock, London.

Carpenter,D \& Peterson D. (2012). Action as the core of work psychology: a German approach. In Handbook of Industrial and Organizational Psychology, Vol. 4, ed. HC Triandis, MD Dunnette, LM Hough, pp. 271340. Palo Alto, CA: Consult. Psychol. Press. 2nd ed.

Chanambam, S.T. (2006). Customer Satisfaction and Service Quality; Customer's Re-Patronage Perspectives. Global Journal of Management and Business Research, Vol.10 (6), pp.83-

Cherkassky, K., (2006). A Market Oriented Strategy for Small and Medium-Sized Enterprises.

Chowdhury , F( 2011). Mater. Disinfection byproducts in Canadian provinces: associated cancer risks and associated medical expenses. 187: 574-584

Clipson, P. (2001), “Culture and leadership: developing an international perspective in educational administration", UCEA Review, Vol. 36 No. 1, pp. 3-7.

Coad, D.A. Zacharakis, A. \& A. Samuel(2013). - Venture Capitalist' Expertise: a Call for Research into Decision Aids and Cognitive Feedback\|. Journal of Business Venturing, 17(1), 1-20.

Cooper, C. (2001). The anatomy of rejuvenation stage of the TALC. In R.W. Butler (ed.), The Tourism Area Life Cycle: Vol. 2; Conceptual and Theoretical Issues. Clevedon, UK: Channel View Publications, 183 200.

Cooper, C. \& Edgett, C., (2007). Survival of the fittest? Entrepreneurial human capital and the persistence of underperforming firms.Admin. Sci. Quart.42750-783.

Covin, J. G. and Slevin, D. P., 1989. Strategic management of small firms in hostile and benign environments. Strategic Management Journal, 10 (1), 75-87.

Cronbach, L. J. (2012). Response sets and test validity. Educational and Psychological Measurement, 6,475-494.

Dallal, G. (2012). The Regression Effect. Retrieved 26th November 2012 from www.jerrydallal.com

Davidsson, P., Delmar,F. \& Wiklund, J. (2006) - Entrepreneurship as Growth: Growth as Entrepreneurship - In Davidsson, P, Delmar, F, \& Wiklund, J (Eds.) 'Entrepreneurship and the Growth of Firms', Edward Elgar Publishing, United Kingdom, England, Cheltenham, pp. 21-38

Davidsson, P., Delmar, F, \& Wiklund, J. ( 2006). Entrepreneurship and growth of firms. Cheltenham,UK: Edward Elgar

David, G., \& Honing, A. (2003). Entrepreneurial charecteristics among unoiversity students: some insights for Entrepreneurship education and training in Turkey. 48 No 1 (10-11-08).

Davidson, S. F., Henry, W. P., \& Strupp, H. H. (2010). Measuring adherence and skill in time-limited dynamic psychotherapy. Unpublished manuscript, Vanderbilt University.

Delmar, B. M., \& Wiklund, D. (2003). The issue of measurement invariance revisited. Journal of Cross Cultural Psychology, 34,155-175.

Delmer,F, Wiklund J and Mckelvie A (2008) What about new entry? Examining the theorized role of new entry in entrepreneurial orientation research. International Small Business Journal 33(4): 351-373.

Dickson, I. (2018). Nature and Operation of Attitudes. Annual Review of Psychology, Vol. 52(1), pp.27-58.

Dobbs, D.A. \& Hamilton, A. (2007). Speed to Initial Public Offering of VC-backed Companiesll. Entrepreneurship Theory and Practice, 25,(3), 59-69.

Dollinger, M.J. (2006). Entrepreneurship Strategies and Resources Third Edition. Pearson Education Ltd, New Delhi India.

Douglas, W. A. (2013). Self-appraised problem solving ability, stress, and suicide ideation in a college population. Unpublished masters thesis, University of Missouri, Columbia.

Drucker, P. (1985).Innovation and entrepreneurship: Practice and principles. New York: Harper and Row.

Drucker, P.(2005). Innovation and Entrepreneurship. Oxford: Butterworth Heineman.

Dushmtsky, R. C., \& Lenox, J. D. (2005). Design and development research. Mahwah, NJ: Lawrence Erlbaum Associates, Publishers.

Dutta, A. W., \& thornhill, S. (2004). Effect of therapist color-blindness on empathy and attributions in crosscultural counseling. Journal of Counseling Psychology, 51, 387-397.

Ekpo Ufot D. B., Nyong, M. O. (2002). Small and medium-scale enterprises in Nigeria: their characteristics, problems and sources of finance. African Economic Research Consortium. Zakuna Printers Ltd, Nairobi, Kenya.

Ekpo-Ufot, A. (2002). The State of the Arts of Finance-Accounting Management in Some

Lagos Organisations in the Chemical Industry: An Exploratory Study, in Ojo, J.A.T. (ed), Business Performance 
Improvement Through Cost Management, Lagos: University of Lagos Press.

Erin L. Scott ,Pian Shu \& Roman M. Lubynsky (2015). Are "Better” Ideas More Likely to Succeed? An Empirical Analysis of Startup Evaluation Copyright (C)

Franklin, M. (2018). Toward a psychology of entrepreneurship - an action theory perspective. Found. Trends Entrepr.5(6):437-96

Fraser, A. (2015). Entrepreneurial entry in to foreign markets. Entrepreneurship: Theory and practice , 23-40.

Freel, L. (2005). Spiritual values and practices related to leadership effectiveness. The leadership quarterly, 16(5), 655-687. http://dx.doi.org/10.1016/j.leaqua.2005.07.003

Frese M. (2000).Success and Failure of Micro business Owners in Africa: A Psychological Approach. Westport, CT: Quorum/Greenwood

Frese M. (2009). Toward a psychology of entrepreneurship - an action theory perspective. Found. Trends Entrepr.5(6):437-96

Frese M, Krauss SI, Keith N, Escher S, Grabarkiewicz R, et al. 2007. Business owners'action planning and its relationship to business success in three African countries.J. Appl. Psychol.92(6):1481-98

Frese M, Kring W, Soose A, Zempel J. 1996. Personal initiative at work: differences between East and West Germany.Acad. Manag. J.39(1):37-63

Frese M, Van Gelderen M, Ombach M. 2000. How to plan as a small scale business owner: psychological process characteristics of action strategies and success.J. Small Bus. Manag.38(2):1-18.

Ganz, D. A. (2009) Chicana and Mexican immigrant women at work: The impact of Class, Race, and Gender on Occupational Mobility, Gender and Society, 3, pp. 37-52.

Ganz, A. (2002), On the growth of micro and small firms: Evidence from Sweden. Small Business Economics, 17, 213-228.

Gangadhara Rao, N (1986), Entrepreneurship and Growth of Enterprise in Industrial Estate, Deep \& Deep Publications, New Delhi,1986, p. 131

Gans, A., \& Sterm, N. (2003), SME Policy, financial structure and Firm growth: Evidence from Japan. Small Business Economics, 27, 289-300.

Galbraith, B. (2003). Feeling good: The new mood therapy. New York: The New American Library.

Gergen, K. J. (2009). An invitation to social construction (2nd ed.). Thousand Oaks, CA, : Sage Publications Ltd.

Gibson, J (2000). The sustainability of the entrepreneurial orientation - Performance relationship. Entrepreneurship: Theory \& Practice24(1): 37-48.

Gielnik MM, Barabas S, Frese M, Namatovu-Dawa R, Scholz FA, et al. (2013). A temporal analysis of how entrepreneurial goal intentions, positive fantasies, and action planning affect starting a new venture and when the effects wear off.J. Bus. Ventur.In press. doi: 10.1016/j.jbusvent.2013.09.002

Gielnik MM, Frese M. (2013). Entrepreneurship and poverty reduction: applying I-O psychology to microbusiness and entrepreneurship in developing countries. InUsing Industrial-Organizational Psychology for the Greater Good: Helping Those Who Help Others, ed. JB Olson-Buchanan, LL Koppes Bryan, L Foster Thompson, pp. 394-438. New York: Routledge

Gielnik MM, Frese M, Stark MS. (2013). Planning and entrepreneurship. InPlanning in Organizations: The Psychology of Performance, ed. MD Mumford, M Frese. In press Gielnik MM, Krämer A-C, Kappel B, Frese M. (2012). Antecedents of business opportunity identification and innovation: investigating the interplay of information processing and information acquisition. Appl. Psychol. In press. doi: 10.1111/j.1464-0597.2012.00528.x

Gintra, C. E., Terwiesh, \& ulrich, Y.A. (2010). A model for mandatory use of software technologies: $A n$ integrative approach by applying multiple levels of abstraction of informing science. Informing Science Journal, 13, 177 - 203. Retrieved from http://www.inform.nu/Articles/Vol13/ISJv13p177-203Koh561.pdf

Goode, W.J. and Hatt, P.K.(2000). Methods in Social Research. New York: McGraw-Hall.

Gora, T. A., (2012). Building resilience or providing sustenance: Different paths of emergent ventures in the aftermath of the Haiti earthquake. Academy of Management Journal, 59(6): 2069-2102.

Green , F. (1995). Management skills and senior management effectiveness. International Journal of Public Sector Management, 8, 3, 52-68.

Green, G. T. (1995). The Teaching of Biology in Tropical Secondary Schools. London: Oxford University Press.

Grant AM, Fried Y, Parker SK, Frese M. (2010). Putting job design in context: introduction to the special issue. Journal. Organ. Behav.31:145-57

Grichnik D, Brinckmann J, Singh L, Manigart S. 2013. Beyond environmental scarcity: human and social capital as driving forces of bootstrappingactivities.J. Bus. Ventur.In press. doi: 10.1016/ j.jbusvent.2013.02.006 Gruber M. 2007. Uncovering the value of planning in new venture creation: a process and contingency perspective.J. Bus. Ventur. 22(6):782-807

Hair, J. F., Black, W. C., Babin, B. J., \& Anderson, R. E. (2010). Multivariate data analysis(7th ed.). Upper Saddle River, NJ: Prentice Hall. 
Hamilton, L. C. (2007).Regression with Graphics. Duxbury Press, Belmont, CA

Hambrick DC. (2007). Upper echelons theory: an update.Acad. Manag. Rev.32(2):334-43

Hanrik, J (2007). Strategic process effects on the entrepreneurial orientation-sales growth rate relationship. Entrepreneurship: Theory \& Practice 30(1): 57-81.

Han, S.-S., Moon, S.J. \& Yun, E.K. (2009). Empowerment, job satisfaction, and organizational commitment: comparison of permanent and temporary nurses in Korea, Applied Nursing Research, (22), 15-20.

Hansen N. (2001). Knowledge workers, communication, and spatial diffusion. In: Johansson B , Karlsson C , Stough RR (eds) Theories of endogenous regional growth: Lessons for regional policies. Springer, Berlin.

Hayward MLA, Forster WR, Sarasvathy SD, Fredrickson BL. (2010). Beyond hubris: how highly confident entrepreneurs rebound to venture again.J. Bus. Ventur.25(6):569-78 435 www.annualreviews.org The Psychology of Entrepreneurship Annul. Rev. Organ. Psychol. Organ. Behav. 2014.1:413-438. Downloaded from www.annualreview

Heek, D (2013). Governance, social identity, and entrepreneurial orientation in closely held public companies. Entrepreneurship: Theory \& Practice35(5): 1051-1076.

Henkel, R.M. (2015) Blending Qualitative and Quantitative Research in Theses and Dissertations, London Sage Publications.

Howell, P. R., (2015). Counterproductive behaviours at work. Handbook of industrial, work, and organizational psychology.London: Sage, 1, 145-164http://dx.doi.org/10.4135/9781848608320.n9

Huselid, M.A. (1995). The impact of human resource management practices on turnover, productivity, and corporate financial performance, Academy of Management Journal, 38, 635-72.

Hyylinen, M.T.S. (2015). Intention to Patronize Halal Restaurants Among Malaysian Muslims-An Issue of Halal Perception. The International Conference on Social Sciences and Humanities, UniversitisiansMalaysia.

Joseph F. Hair, Jr,William C. Black,Barry J. Babin and Rolph E. Anderson(2010). Multivariate Data Analysis, 7th Edition (C2010 |Pearson

Johnson, J. L. (1999). - Strategic Integration in Industrial Distribution Channel: Managing the Inter-firm Relationship as a Strategic Assetll, Journal of the Academy of Marketing Science, 27(1): 4

Kanungo.R., \& Schindler Misra. (1992). Business Research Methods. (10th ed). Singapore: McGraw-Hill.

Kaplan, R. S. \& Norton D.P. (1992). The Balanced Scorecard-Measures That Drive Performance. Harvard Business Review, January-February 1992, 71-79.

Kalleberg, A. L., K. T. Liecht. 1991. Gender and organizational performance: Determinants of small business survival and success. Acad. Management J.34136-161.

Katila , E. A. (2002). Businessmen bemoan infrastructure deficit, security. Available at http://www.punchng.com/business/business-economy/businessmen-bemoan-infrastructuredeficitinsecurity/

Kehinde, O.J., Abiodun, A.J. Adegbuyi, O. and Oladimeji, H. (2016). Small and Medium Scale Enterprises: Pivotal to Sustainable Economic Development: The Nigeria Experience.

Kellogg, R (2008). A Needs Analysis of Financial Management and Accounting Skills in the SME sector in KwaZulu-Natal. Thesis submitted to University of KwaZulu-Natal, Pietermaritzburg (Unpublished).

Kerlinger, M (1964). The shadow of death: An empirical analysis of the pre-exit performance of new German firms. Small business economics, 23, 189-201.

Kerlinger, F. (2003). Foundations of Behavioural Research. New York: Holt, Rinehart and Winston.

Knack, S. \& Keefer, P. (1997). Does social capital have an economic payoff? A crosscountry investigation, The Quarterly Journal of Economics, 112 (4), 1251-88.

Lin, F. M. (2017). Role of business management into the success and survival of small business: the case of star learning centre in Botswana. International Journal of Business Administration, 3, 1, 93-112.

Lowe, T. \& Mariotte, R.M. (2010). Proceedings of workshop stakeholders, policy makers and regulators of street food in Accra (eds), DFID/NRI/FRI crop post harvest programme project.

Lenox, J (2011). Understanding the manifestation of entrepreneurial orientation in the nonprofit context. Entrepreneurship: Theory \& Practice35(5): 947-971.

Levine, R. (1997). - Financial Development and Economic Growth: Views and Agendall

Lin, S. \& Huang Y. (2005). The role of social capital in the relationship between human capital and career mobility, Journal of Intellectual Capital, 6, (2), 191-205.

Lumpkin, G.T. \& Dess, G.G. (1996). Clarifying the entrepreneurial orientation construct and linking it to performance. Academy of Management Review, 21(1), 135-172.

Lundvall, M. O. (2007). Being paper presented at 2004, Annual Management Conference of Nigerian Institute of Management (Chartered) at International Conference Centre, Abuja.

Mackinnon, P. D., \& OrDerickson, J. E. (2012). Practical research: Planning and design(9th ed.). Upper Saddle River, NJ: Prentice Hall.

Mckenzie, O. (2009). Access to capital, capital structure, and the funding of the firm. The Journal of Finance, 
$64\{1), 263-308$.

McAdam, C. A., \& Mcclellard, R. A. (2002). Advanced and multivariate statistical methods: Practical application and interpretation(4th ed.). Los Angeles,CA: Pyrczak Publishing.

Mcfadzaen , J. (2009). New spurs for Europe's small firms, Research Technology Management, 52, 3, 5-7

McKenzie, J., Woolf, N., Van Winkelen, C. \& Morgan,C. (2009). Cognition in strategic decision making: $a$ model of non-conventional thinking capacities for complex situations, Management Decision, 47, (2), 20932.

Meichebaum.G (1977). Marketing at the interface: not 'what' but 'how', Journal of Marketing Theory and Practice, 8, 2, 1-7.

Meichenbaum, D. H. (1972). Cognitive modification of test anxious college students. Journal of Clinical and Counseling Psychology, Vol. 39, No. 2. pp. 370-380.

Miguez,R.A (2012). A process model of internal corporate venturing in the diversified major firm. Administrative Science Quarterly28(2): 223-244.

Ministry of industry. (2017). National research council Canada IRAP financial assistance. Retrieved January 23, 2012, from http://www.nrccnrc.gc.ca/eng/services/irap/financial-assistance.hlml 231

Mintzberg, H. (1973). Strategy making in three modes. California Management Review, 16, 44-53.

Mugenda, A \& Mugenda, O. (2009). Research Methods: Quantitative and Qualitative Approaches. Acts Press. Nairobi, Kenya.

Mugenda, O. M., \& Mugenda, A. G. (2003). Research methods: Quantitative and qualitative approaches. Nairobi: Acts Press.

Nason, R., \& Wiklund, J. (2018). An assessment of resource-based theorizing on firm growth and suggestions for the future. Journal of Management, 44(6): 1820-1853.

OECD. (2011). Greening Household Behaviour. Paris: OECD Publishing.Organisation for Economic Cooperation and Development (O E C D ) (2009). The Impact of the Global Crisis on SME and Entrepreneurship Financing and Policy Responses, Centre for Entrepreneurship, SMEs and Local Development, OECD Publishing.

Ogwo,O.E. \& Igwe, S.R. (2012). Some keys factors influencing Attitudes to patronage of GSM services: The Nigerian experience. International journal of and Management, Vol.7 (18), pp. 82-91. DOI:10.5539/ijibm.vtn18p82

Okonkwo , A. (2007). Entrepreneurs' Reported Challenges and Opportunities of Global Financial Crisis on Small Business Operations in Anambra and Ekiti States, Nigeria. Paper presented at Global Awareness Society International 22 nd Annual Conference-Rome, Italy, May 2013.

Olayinka Moses, Joseph Femi Adebisi (2013). Small Business Financing in Nigeria: An Investigation of The Angel Option. Canadian Social Science, 9(2), 93-98. Available from:http://www.cscanada.et/index.php/css/article/view/j.css.1923669720130902.719 DOI: http://dx.doi.org/10.3968/j.css.1923669720130902.7193

Paul, R. and Elder, L. (2010). The Miniature Guide to Critical Thinking Concepts and Tools. Dillon Beach: Foundation for Critical Thinking Press

Patel, J and Conklin D (2012) Knowledge-based resources, entrepreneurial orientation, and the performance of small and medium-sized businesses. Strategic Management Journal24(13): 1307-1314.

Paunor, O.,(2014). Contextualization and the advancement of entrepreneurship research. International Small Business Journal32(5): 479-500.

Pfeffer, J. (2005). Producing sustainable competitive advantage through effective management of people. Academy of Management Executive, 18 (4), 95-105.

Pfeffer, J. (1994). Competitive advantage through people: Unleashing the power of the work force. Boston: Harvard Business School Press.

Philips, L. E. (1971). Evolution and revolution as organizations grow. Harvard Business Review,76(3),5568.Grove, A. Retrieved October/15,2004,fromhttp:/www.intel.com/pressroom/kits/bios/grove/paranoid.htm Philips, B.S. (1971). Social Research: Strategy and Tactics. 2nd Ed. New York: Macmillian.

Podsakoff, P. M., MacKenzie, S.B., Paine, J. B., \& Bacharach, D. G. (2012). Organizational citizenship behaviours: A critical review of the theoretical and empirical literature and suggestions for future research. Journal of Management, 26, 513-563.

Prahalad,H and Krishnan, Y (2008) Entrepreneurial orientation and firm performance in new ventures and established firms. Journal of Small Business Management49(4): 558-577.

Rauch, A., Wiklund, J., Lumpkin, G.T., \& Frese, M. (2009). Entrepreneurial orientation and business performance: An assessment of past research and suggestions for the future. Entrepreneurship Theory and Practice, 33(3), 761-787.

Rauch, A. (2010). The relationship between small business market orientation and environmental uncertainty. Marketing Intelligence and Planning, 30, 7, 757-779. 
Rauch, A., Frese, M. (2007), "Let's Put the Person Back into Entrepreneurship Research: A Meta-Analysis on the Relationship Between Business Owners' Personality Traits, Business Creation and Success." European Journal of Work and Organizational Psychology, Vol. 16, pp. 353-385.

Rauch, A. (2010), “Dispositions of Entrepreneurs: Exploring Entrepreneurs' Personality Characteristics. ” In M. Lukes, M. Laguna (Eds.), Entrepreneurship: A Psychological Approach(pp. 37-54), Prague: Oeconomica.

Rauch, A., Frese, M. \& Utsch, A. (2005). Effects ofhuman capital and long-term human resources development and utilization on employmentgrowth of small-scale business: a causal analysis, Entrepreneurship Theory and Practice, 30, 681-98.

Rausch, E. (2007). Leadership in management education and development: criteria for quality decisions, European Business Review, 19, (3), 257 - 268

Robinson, J. and Mcdougal,D. (2001) Where to from here? EO-as-experimentation, failure, and distribution of outcomes. Entrepreneurship: Theory \& Practice35(5): 925-946.

Rogers P. \& Blenko M. (2006). The high-performance organization: making good decisions and making them happen, Handbook of Business Strategy, 7 (1), 133 - 142.

Rogers, E.M. (2003). Diffusion of Innovation, Free Press, New York, NY.

Rose, Y (2006). A systems approach to conduct an effective literature review in support of information systems research. Informing Science Journal, 9, 181-212. Retrieved from http://www.inform.nu/Articles/Vol9/V9p181-212Levy99.pdf

Russel, M. , \& faulker, J. (2004). Internal intellectual assets: A management interpretation. Journal of Information. Information Technology, and Organizations, 6, 1-13.

Saunders,M.,Lewis,P and Thornhill,A. (2006) Understanding Research Approaches, London, SAGE Publications.

Samuelson, P. E., \& Davidson, S. (2009). The Stressor-Emotion Model of Counterproductive Work Behavior. Washington, DC: American Psychological Association

Saunders, M. \& Lewis, P. \& Thornhill, A. (2007). Research Methods for Business Students,Pearson Education Limited, India.

Saunders, M., Lewis, P. and Thornhill, A. (2007) Research Methods for Business Students. 4th Edition, Financial Times Prentice Hall, Edinburgh Gate, Harlow.

Sasi, F., \& Sendil, W. (2000). Arriving at the high- growth firm. Journal of Business Venturing, $18(2), 189$-216

Schillo, S. (2011). Entrepreneurial Orientation and Company Performance: Can the Academic Literature Guide Managers? Technology Innovation Management Review, November, 20-25.

Schumpeter, J.A. (1934).The theory of economic development. Cambridge, MA: Harvard Press.

Scarborough, P., and Zimmer,C (1999). "Toward a Reconciliation of the Definitional Issues

in the Field of Corporate Entrepreneurship," Entrepreneurship: Theory \& Practice23(3), 11-27.

Schumpeter, J.(1934), "The Theory of Economic Development." Cambridge, MA: Harvard University Press. (Translation of the original German work titled Theorie der Wirtschaftlichen Entwicklung)

Sekaran, U. (2006). Research methods for business: A skill building approach. New Delhi: John Wiley \& Sons

Sekaran, U., \& Bougie, R. (2010). Research methods for business: A skill building approach (5th ed.). West Sussex, UK: John Wiley \& Sons Ltd.

Selltiz, J. (1976). The population ecology of organizations. The American Journal of Sociology, 82(5), 929-964.

Selltiz, C.; Wrightsman, L; and Cook, S. (1976). Research Methods in Social Relations. 3rd Ed. New York, Holt, Rinehart and Winston.

Seo,H, Lee JM \& Nam J. (2012). Understanding when bad moods foster creativity and good ones don't: the role of context and clarity of feelings.J. Appl. Psychol.87(4):687-97 Sivaloganathan. D. (2004). Qualitative research in information systems. MIS Quarterly, 21(2), 241242.

Singleton, R.W. (1913). Translation and content analysis of oral and written materials. In H.C. Triandis \&J.W. Berry (Eds.),Handbook of cross-cultural psychology(Vol. 2, pp. 389-444).

Singleton, R.A., Straits, B.C. and Straits, M.M. (1993). Approaches to Social Research. 2nd Ed. New York: Oxford University Press.

Slevin J (2009) The sustainability of the entrepreneurial orientation. Performance relationship. Entrepreneurship: Theory \& Practice24(1): 37-48.

Smith, H. W (1989). Comparative Evaluation of three Teaching Methods of Quantitative Technique Traditional Lecture, Socratic Dialogue and Personalized System of Instruction (PSI) Format. Journal of Experimental Education. 55 (3) $149-154$.

Stevens, W. H. (1951). Theory of the firm: Managerial behavior, agency costs and ownership structure. Journal of Financial Economics, 3(A), 305-360.

Stiglian, D.A. (2012). Learning Form Business Failures: Proposition about the Grief Recovery Process for the Self Employed.\| Academy of Management Review, 28, 318-329.

Steinberg, J., (2012). The Management of Business Finance. The Bath Press, Avon. Great Britain.

Stuart, M., hoang, N.,\& Hybel, I. (1999). Guiding the use of grounded theory in doctoral studies - An example 
from the Australian film industry. International Journal of Doctoral Studies, 6, 95-114. Retrieved from http://ijds.org/Volume6/IJDSv6p095-114Jones322.pdf

Subramaniam, M. \& Youndt, M. (2005). The influence of intellectual capital on the types of innovative capabilities, Academy of Management Journal, 48 (3), 450-64.

Swedberg U., (2002). Research Methods for Business: A skill Building Approach. New York: John Wiley \& Sons Inc.

Tabachnick, B. G., \& Fidell, L. S. (2007). Using Multivariate Statistics (5th ed.). New York: Allyn and Bacon

Thomas, P., \& Muller, A. (2000). Qualitative methods in business research, London, UK: Sage.

Thomas, A. S., \& Muller, S. L. (2000). A case for comparitive entrepeneurship: assesing the relivance of culture. journal of international business studies, 31 No 2, 287-301.

Thornhill, S., R. Amit. (1998). Growth management of emergent firms in Canada. P. Reynolds et al. eds. Frontiers of Entrepreneurship Research. Babson College, Babson Park, MA, 381-392.

Tidd . H \& Bessant.K (2011). 'A Literature Review on Skills and Innovation. How Does Successful Innovation Impact on the Demand for Skills and How Do Skills Drive Innovation?' A CRIC report for the Department of Trade and Industry, September 2011.

Toulouse, C. E. (2006). Almost everything you ever wanted to know about how to do process research on counseling and psychotherapy but didn't know how to ask. In C. E. Watkins, Jr. \& L. J. Scheider (Eds.), Research in counseling (pp. 85-118). Hillsdale, NJ: Lawrence Erlbaum.

Tsvetkova, S. L., (2014). A typology of deviant workplace behaviors: A multidimensional scaling study. Academy of management journal, 38(2), 555-572. http://dx.doi.org/10.2307/256693

Ulijin, C.., \& Brown, M. (2004).Ownership structure, lending bias, and liquidity constraints: Evidence from Shanghai's manufacturing sector. Journal of Comparative Economics, 26, 300-316

Ulrich, D., \& Lake, D. (1990) Organizational capability: Competing from inside out.New York: Wiley

UNWO(2011). An illustration using entrepreneurial orientation. Organizational Research Methods13(2): 320347.

Verworm, G. (2006), The determinants of growth for small and medium sized firms. The role of the availability of external finance. Small Business Economics, 19, 1-16.

Wang, S. J., \& Wang, P. (2012) The relationships of age and length of service with job satisfaction: an examination of hotel employees in Thailand, Journal of Managerial Psychology, 18(7), pp. 745-758.

Wagner, S.; \& Roger, H.C. (2010). Testing the sufficiency of the Theory of Planned Behavior: a case of customers dissatisfaction responses in restaurants. Hospitality Management Journal, Vol. 24, pp.475-792.

Wagner, T. \& Hoolenbeck, G. (2010). The antecedents and consequences of psychological empowerment among Singaporean IT employees, Management Research News, 30 (1), 34-46.

Ward, R. (2004). Business Failure Rate. American Journal of Small Business, 6, 2, 17-25.

Wakkee R, Schmitt A, Frese M, Kuehnel J. (2015). The affective shift model of work engagement.J. Appl.Psychol.96(6):1246-57

Woodman, J. W. (2005). —Racial Differences in Job Attitudesll, Journal of Applied

Wright, P. M.,\& McMahan, G. C. (1992). Theoretical perspectives for strategic HRM. Journal of Management, 18, 295-320. www.scac.go.ke(2011) List of Kenyan state corporations. Retrieved in July, 2011.

Zaltman, B.R. (2003). Toward a multidimensional model of entrepreneurship: The case of achievement motivation and the entrepreneur. Entrepreneurship Theory and Practice14:39-54.

Zikmund,. R. (2010). Innovation: The key to success in small firms. Ottawa: Statistics Canada

Zikmund, W.G. (2003). Business Research Methods ( $7^{\text {th }}$ ed.). Indiana, United States of America: Thomson Publishers

Zverinova and Scagny (2012). Entrepreneurship and its determinants in a cross-country setting.J. Evol. Econ. 17(2):117-31 